\title{
PENGARUH KUALITAS PELAYANAN TERHADAP MINAT BELI PADA MASA PANDEMIK COVID-19 204 DI KANTIN YUANK KOTA BIMA (Studi Kasus Pada Pengunjung Kantin Yuank Kota Bima)
}

\author{
Winda'; Firmansyah Kusumayadi² \\ 2 Program Studi Manajemen, STIE Bima, Nusa Tenggara Barat, Indonesia ${ }^{1,2}$. \\ windastieg9@gmail.com ${ }^{1}$, firmansyah.stiebima@gmail.com²
}

\begin{abstract}
ABSTRAK
Kualitas pelayanan merupakan salah satu dari kegiatan-kegiatan pokok yang dilakukan oleh Kantin Yuank dalam usahanya untuk berkembang dan mendapatkan laba. Oleh karena itu penelitian ini bertujuan untuk mengetahui pengaruh kualitas pelayanan terhadap minat beli pengunjung pada masa pandemik covid 19 di Kantin Yuank Kota Bima. Metode penelitian menggunakan metode kuantitatif dengan sumber data primer. Sampel pada penelitian ini 96 responden dengan metode non-probability sampling dengan teknik accidental sampling. Penelitian dilakukan dengan pembagian kuesioner. Analisis data pada penelitian ini meliputi uji validitas dan reliabilitas, regresi liniear sederhana, koefisien korelasi, koefisien determinasi $\left(\mathrm{R}^{2}\right)$ serta pengujian hipotesis melalui uji $t$. Pengujian hipotesis menggunakan uji $t$ menunjukkan bahwa variabel independen kualitas pelayanan yang diteliti terbukti secara signifikan mempengaruhi variabel dependen minat beli konsumen dengan nilai p value sebesar o,ooo lebih kecil dari 0,05 $(0,000<0,05)$. Adjusted R Square diperoleh sebesar 0,251. Hal ini berarti 25,1\% minat beli di pengaruhi oleh kualitas pelayanan dan sisanya 74,9\% disebabkan oleh faktor lain yang tidak termasuk dalam penelitian ini seperti kualitas produk, harga, tempat dan lainlain. Hasil penelitian menunjukkan bahwa kualitas pelayanan mempengaruhi minat beli. Dengan demikian, dengan menjaga dan meningkatkan kualias produk dan kualitas pelayanan di Kantin Yuank Kota Bima, maka akan terbentuk sikap pengunjung yang positif dimana akan mempengaruhi minat beli pengunjung di Kantin Yuank Kota Bima
\end{abstract}

Kata Kunci : Kualitas Pelayanan, Minat Beli

\begin{abstract}
Quality of service is one of the main activities carried out by Kantin Yuank in its efforts to develop and earn a profit. Therefore, this study aims to determine the effect of service quality on visitor buying interest during the Covid 19 pandemic at the Yuank Canteen in Bima City. The research method uses quantitative methods with primary data sources. The sample in this study was 96 respondents using non-probability sampling method with accidental sampling technique. The research was conducted by distributing questionnaires. Data analysis in this study includes: validity and reliability tests, simple linear regression, correlation coefficient, determination coefficient (R2) and hypothesis testing through $t$ test. Hypothesis testing using the $t$ test shows that the independent variable quality of service studied is proven to significantly affect the dependent variable consumer purchase interest with a p value of o.0oo less than 0.05 (o.0oo <0.05). The Adjusted $R$ Square is 0.251 . This means that $25.1 \%$ of buying interest is influenced by service quality and the remaining $74.9 \%$ is caused by other factors not included in this study such as product quality, price, place and others. The results showed that service quality influenced purchase intention. Thus, by maintaining and improving product quality and service quality at the Yuank Canteen in Bima City, a positive visitor attitude will be formed which will affect the buying interest of visitors at the Yuank Canteen in Bima City.
\end{abstract}




\section{Keywords: Quality of service, purchase interest}

Diterima: 14 September 2021; Direvisi: 29 September 2021; Diterbitkan: Oktober 2021

\section{PENDAHULUAN}

Virus Corona atau Covid-19 merupakan virus yang melanda dunia saat ini, termasuk Indonesia. Dengan adanya pandemic virus Covid-19 ini yang menyebar ke seluruh dunia maka menyebabkan terbatasnya aktivitas kegiatan manusia, sektor - sektor industri atau perusahaan menurunkan atau bahkan menghentikan produktivitasnya. Pandemic virus corona ini pun bahkan mampu memukul kemunduran ekonomi hampir seluruh dunia. Selain memburuknya kondisi ekonomi glodal akibat pandemic ini, virus corona turut menekan dunia usaha di Indonesia, termasuk di sektor usaha mikro, kecil, dan menengah (UMKM). Salah satu pelaku usaha di wilayah Kota Bima yang bergerak di dalam bidang penjualan franchice serta makanan dan minuman mengakui kondisi pasca pandemic ini sangat mempengaruhi tingkat penjualannya, karna dalam kasus ini semua lapisan masyarakan baik itu lapisan atas, menegah dan bawah terkena dampak dari virus corona yang mengakibatkan turunnya pendapatan dan daya beli masyarakat.

Sikap konsumen dan minat beli di sebuah coffee shop dipengaruhi beberapa hal, seperti kualitas produk yang terjamin, kualitas pelayanan, dan kenyamanan tempat. Trend bisnis atau usaha Start-Up atau kantin saat ini sedang berkembang terutama dikalangan anak muda. Usaha Kantin atau usaha Start-Up yang berhasil mendapat pendanaan memiliki strategi yang lebih baik. Salah satu bisnis atau usaha Kantin yang ada di Kota Bima adalah Kantin Yuank yang terletak di Kelurahan Paruga
Kecamatan Rasanae Barat Kota Bima saat ini ramai dikunjungi pelanggan karena menawarkan beberapa jenis produk dengan iringan music, sehingga menarik minat para pengunjung.

Kantin Yuank adalah salah satu tempat nongkrong asik di Kota Bima yang banyak diminati oleh masyarakat di Kota Bima. Kantin Yuank menyediakan makanan dan minuman siap saji serta menyediakan layanan antar. Kantin Yuank juga dikenal dengan harganya yang lebih murah dan variasi produk yang lengkap serta baru. Sebelum adanya pandemi covid 19, Kantin Yuank ini selalu ramai dengan antrian yang cukup panjang namun pelayanannya tetap baik dan menyenangkan. Setelah adanya pandemik covid 19 pengunjung Kantin Yuank ini juga masih banyak, sehingga pemilik harus membuat kebijakan untuk menjaga keselamatan karyawan maupun pelanggan. Kebijakan yang ditetapkan terkait dengan perubahan Kualitas Pelayanan non fisik meliputi standar dan prosedur harus menggunakan masker dan sarung tangan, tidak bersentuhan dengan rekan maupun pelanggan, mewajibkan sering cuci tangan bagi karyawan dan penyemprotan hand sanitizer pada pelanggan yang datang, membatasi pelanggan yang masuk ke cafe, dan tidak boleh melayani pelanggan yang tidak menggunakan masker.

Kualitas pelayanan merupakan faktor dan akar penting yang mampu memberikan kepuasan bagi pelanggannya yang terkait dengan hasil perilaku dari mulut ke mulut, keluhan, rekomendasi dan pertukaran atau perpindahan. Adhiyanto

(2012) 
menyatakan bahwa dengan adanya kualitas pelayanan yang baik di dalam suatu perusahaan, akan menciptakan kepuasan bagi para pelanggannya. Setelah pelanggan merasa puas dengan produk atau jasa yang diterimanya, pelanggan akan membandingkan pelayanan yang diberikan. Apabila pelanggan merasa benar-benar puas, mereka akan membeli ulang serta memberi rekomendasi kepada orang lain untuk membeli di tempat yang sama, oleh karena itu perusahaan harus memulai memikirkan pentingnya pelayanan pelanggan secara lebih matang melaui kualitas pelayanan.

Kualitas pelayanan merupakan salah satu dari kegiatan-kegiatan pokok yang dilakukan oleh Kantin Yuank dalam usahanya untuk berkembang dan mendapatkan laba. Sebuah usaha dagang dikatakan berhasil menjalankan fungsinya apabila mampu menjual produknya pada konsumen dan memperoleh profit semaksimal mungkin. Tujuan kualitas pelayanan bagi konsumen sebagai salah satu untuk menarik minat beli atas produk yang di pasarkan. Maka dalam hal ini Kantin Yuank sangat penting untuk mengetahui apa yang menjadi faktor-faktor yang mempengaruhi minat konsumen/pengunjung untuk tetap loyal pada produk yang telah dipasarkan.

Minat beli adalah kegiatan-kegiatan individu yang secara langsung terlibat untuk menggunakan barang dan jasa termasuk di dalamnya proses pengambilan keputusan pada persiapan dan penentuan kegiatankegiatan tersebut. Minat beli timbul setelah konsumen menerima indikator dari sesuatu yang mereka lihat, pada saat konsumen memasuki sebuah toko saat itulah timbul perhatian, keingintahuan, bahkan keinginan untuk mencoba dan kemudian membeli produk tersebut. Minat beli konsumen yang tinggi akan membawa dampak positif bagi usaha dagang untuk mencapai keberhasilan.

Penelitian sebelumnya yang dilakukan oleh Tifa (2010) menjadikan dasar peneliti untuk melakukan penelitian lanjutan pada Kantin Yuank Kota Bima. Hasil penelitian dari Tifa bahwa kualitas pelayanan memiliki pengaruh terhadap minat beli konsumen pada Rumah Makan Boga-Bogi Jogjakarta. Selanjutnya penelitian dari Ananda (2016) Hasil penelitian ini mengatakan bahwa kualitas pelayanan memiliki pengaruh terhadap minat beli konsumen pada Ramayana Lestari Sentosa Pekanbaru

Salah satu usaha yang mengalami dampak dari pandemik covid 19 adalah Kantian Yuank Kota Bima. Selama masa pandemik covid 19 minat beli pelanggan Kantin Yuank terjadi penurunan. Selain disebabkan oleh Pandemik Covid 19 minat beli konsumen dipengaruhi juga oleh kualitas pelayanan karyawan. Adapun penurunan kunjungan yang terjadi dapat dicerminkan oleh berbagai macam bentuk keluhan dari pelanggan. Anggapan dari pelanggan bahwa Kantin Yuank belum memberikan kualitas pelayanan secara maksimal untuk pelanggannya selama masa pandemik covid 10 sehingga membuat para pelanggan merasa kurang puas dan memilih untuk datang ke cafe lainnya.

Namun terlepas dari hal tersebut, berdasarkan hasil penelitian yang dilakukan oleh peneliti di Kantin Yuank Kota Bima terdapat permasalahan yang mempengaruhi menurunnya minat beli pada masa pandemik covid 19 di Kantin Yuank seperti kurangnya spontanitas respon dari karyawan untuk tidak peduli kepada pelanggan yang berkunjung, kurangnya kualitas pelayanan dari karyawan seperti keterampilan karyawan dalam memberikan pelayanan, kecepatan, dan kesigapan dalam melayani pengunjung, kualitas produk makanan dan minuman 
yang disediakan di Kantin Yuank kurang memberikan manfaat yang sanggup memenuhi kebutuhan dan harapan pelanggan serta Interaksi komunikasi antara pengunjung dengan karyawan masih kurang terjalin dengan baik

Dari dasar teoritis tersebut dan data yang ada, peneliti tertarik meneliti lebih lanjut terhadap Pengaruh Kualitas Pelayanan terhadap Minat Beli pada masa Pandemik Covid-19 Di Kantin Yuank Kota Bima (Studi Kasus pada Pengunjung Kantin Yuank Kota Bima).

\section{LANDASAN TEORI}

\section{Kualitas Pelayanan}

Kualitas pelayanan atau jasa adalah keunggulan yang diharapkan dan pengendalian atas tingkat keunggulan untuk memenuhi keinginan pelanggan menurut Tjiptono dan Chandara (2011:172), kualitas pelayanan berkaitan erat dengan kepuasaan pelanggan. Kualitas pelayanan memberikan dorongan khusus bagi para pelanggan untuk menjalin ikatan relasi saling menguntungkan dalam jangka panjang

Sedangkan menurut Lovelock (2011), Kualitas Pelayanan adalah tingkat keunggulan yang diharapkan dan pengendalian atas tingkat keunggulan tersebut untuk memenuhi keinginan pelanggan. Pendapat lain dikemukan oleh Sunyoto (2012:236) bahwa kualitas pelayanan merupakan suatu ukuran untuk menilai bahwa suatu barang atau jasa telah mempunyai nilai guna seperti yang dikendaki atau dengan kata lain suatu barang atau jasa dianggap telah memiliki mutu apabila berfungsi atau mempunyai nilai guna seperti yang diinginkan.
Berdasarkan uraian di atas, maka penulis menyimpulkan bahwa kualitas pelayanan merupakan suatu aktivitas dalam menyempurnakan tingkat kepuasan konsumen pada pembelian produk yang diinginkan

Dalam mengetahui indikator kualitas pelayanan yang secara efektif cenderung pelanggan menentukan produk yang akan dibeli. Menurut Parasuraman, Zeithamal \& Bery dalam Kertajaya (2015) bahwa untuk mengukur kualitas pelayanan yang dirasakan secara nyata oleh konsumen, maka dapat diukur dengan 5 (lima) dimensi yang digunakan konsumen dalam menilai mutu jasa, kelima dimensi dasar tersebut adalah :

1. Reliability, kemampuan untuk memenuhi janji pelayanan kepada konsumen yang diberikan secara akurat, yaitu diselesaikan dengan hasil yang sama dan tanpa adanya kesalahan.

2. Responsiveness, keinginan untuk membantu pelanggan dengan menyediakan pelayanan yang tepat waktu, seperti sensitif terhadap kebutuhan, fleksibel, mau berusaha lebih dari seharusnya, memperhatikan secara personal, keinginan untuk menindak lanjuti dan menyelesaikan masalah.

3. Assurance, pengetahuan, keramahan dari karyawan, serta dapat diberikan kepercayaan dan menjaga kerahasiaan.

4. Empathy, provisi dari memperhatikan dan memberikan perhatian yang bersifat individu kepada pelanggan.

5. Tangibles, penampilan dari fasilitas fisik, peralatan, seragam karyawan dan materi komunikasi.

Minat beli konsumen dipengaruhi oleh kualitas pelayanan. Semakin baik kualitas pelayanan, maka semakin meningkat minat beli sehingga volume penjualan produk meningkat dan meningkat pula pendapatan 
UMKM. Pelayanan karyawan yang ramah dan cepat dapat meningkatkan minta beli konsumen oleh Soehardi (2021) dan Murdayani et al., (2021).

\section{Minat Beli}

Minat beli adalah tahap kecenderungan responden untuk bertindak sebelum keputusan membeli benar-benar dilaksanakan. Terdapat perbedaan antara pembelian aktual dan minat pembelian ulang. Bila pembelian aktual adalah pembelian yang benar-benar dilakukan oleh konsumen, maka minat pembelian ulang adalah niat untuk melakukan pembelian kembali pada kesempatan mendatang (Kinnear \& Taylor, 2010).

Minat beli ulang merupakan minat pembelian yang didasarkan atas pengalaman pembelian yang telah dilakukan dimasa lalu. Minat beli ulang yang tinggi mencerminkan tingkat kepuasan yang tinggi dari konsumen ketika memutuskan untuk mengadopsi suatu produk. Keputusan untuk mengadopsi atau menolak suatu produk timbul setelah konsumen mencoba suatu produk tersebut dan kemudian timbul rasa suka atau tidak suka terhadap produk tersebut. Rasa suka terhadap produk timbul bila konsumen mempunyai persepsi bahwa produk yang mereka gunakan berkualitas baik dan dapat memenuhi atau bahkan melebihi keinginan dan harapan konsumen. Dengan kata lain produk tersebut mempunyai nilai yang tinggi di mata konsumen. Tingginya minat beli ulang ini akan membawa dampak yang positif terhadap keberhasilan produk di pasar (Thamrin, 2012).

Minat beli pada dasarnya adalah perilaku pelanggan dimana pelanggan merespon positif terhadap kualitas produk / jasa dan berniat mengkonsumsi kembali produk tersebut. Menurut Ferdinand dalam
Dwityanti (2008) minat beli ulang dapat diidentifikasi melalu indikator-indikator sebagai berikut:

1. Minat transaksional : yaitu kecenderungan seseorang untuk selalu membeli ulang produk yang telah dikonsumsinya.

2. Minat referensial : yaitu kecenderungan seseorang untuk mereferensikan produk yang sudah dibelinya, agar juga dibeli oleh orang lain, dengan referensi pengalaman konsumsinya.

3. Minat preferensial : yaitu minat yang menggambarkan perilaku seseorang yang selalu memiliki preferensi utama pada produk yang telah dikonsumsi. Preferensi ini hanya dapat diganti bila terjadi sesuatu dengan produk preferensinya.

4. Minat eksploratif : minat ini menggambarkan perilaku seseorang yang selalu mencari informasi mengenai produk yang diminatinya dan mencari informasi untuk mendukung sifat-sifat positif dari produk yang dilanggananinya.

\section{Pengaruh Kualitas Pelayanan Terhadap Minat Beli}

Untuk mempengaruhi minat beli konsumen maka produsen harus terus menerus meningkatkan kualitas pelayanan kepada para konsumen untuk meningkatkan volume penjualan di sebuah usaha. Dalam usaha untuk meningkatkan minat beli konsumen hendaknya seluruh jajaran karyawan menciptakan suatu pelayanan yang diharapkan oleh para konsumen, karena pelayanan yang baik tersebut akan mendorong peningkatan minat beli konsumen. Bariroh (2015) menyatakan bahwa kualitas pelayanan mempunyai pengaruh terhadap minat beli konsumen, dimana ketika kualitas pelayan kurang baik maka akan menurunkan minat beli konsumen. Karena dalam proses 
membeli terdapat evaluasi dan pengambilan keputusan sebelum melakukan pembelian, ketika kualitas pelayanan kurang baik maka akan berdampak pada kepuasan pelanggan dan membuat pelanggan menjatuhkan pilihanya untuk membeli kepada pesaing pada hal ini berarti minat membeli akan berkurang atau menurun. Sebaliknya jika kualitas pelayanan baik maka konsumen akan merasa senang dan kembali lagi membeli dan tidak akan menjatuhkan pilihanya kepada pesaing. Dalam artinya ketika kualitas pelayanan baik maka minat beli konsumen akan bertambah

Teori tersebut mendukung penelitian yang dilakukan oleh Tifa (2010) Hasil penelitian ini mengatakan bahwa kualitas pelayanan memiliki pengaruh terhadap minat beli konsumen pada Rumah Makan Boga-Bogi Jogjakarta. Selanjutnya penelitian dari Ananda (2016) Hasil penelitian ini mengatakan bahwa kualitas pelayanan memiliki pengaruh terhadap minat beli konsumen pada Ramayana Lestari Sentosa Pekanbaru.

\section{Kerangka Penelitian}

Kerangka pemikiran penelitian menggambarkan hubungan dari variabel independen terhadap variabel dependen. Berdasarkan tinjauan pustaka dan penelitian terdahulu maka dibuat kerangka pemikiran sebagai berikut bahwa Minat Beli konsumen dipengaruhi oleh variabel kualitas pelayanan, dapat dilihat pada gambar 2.1 sebagai berikut :

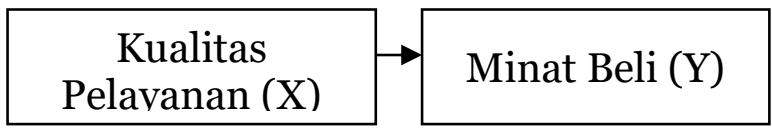

Gambar 2.1 : Kerangka Penelitian

Dari gambar kerangka pikir di atas dapat dikatakan bahwa kualitas pelayanan mempunyai pengaruh terhadap minat membeli konsumen, dimana ketika kualitas pelayanan baik maka konsumen akan merasa senang dan akan kembali lagi untuk membeli dan tidak akan menjatuhkan pilihanya kepada pesaing. Berdasarkan teori di atas, maka penulis dapat menyimpulkan bahwa kualitas pelayanan dapat mempengaruhi minat beli konsumen

\section{Hipotesis Penelitian}

Hipotesis merupakan jawaban sementara yang masih harus dibuktikan kebenarannya melalui penelitian (Sugiyono, 2014). Hipotesis dalam penelitian ini adalah:

H1: Ada pengaruh kualitas pelayanan terhadap minat beli pengunjung di masa pandemik covid 19 pada Kantin Yuank Kota Bima

\section{METODE PENELITIAN}

Jenis penelitian ini merupakan penelitian asosiatif dengan pendekatan kuantitatif yang dinyatakan dalam bentuk skala numerik seperti: data kualitatif yang diangkakan (scoring). Populasi adalah obyek atau subyek yang mempunyai kualitas dan karakteristik tertentu yang telah ditetapkan oleh peneliti (Sugiyono, 2014). Populasi pada penelitian ini adalah pelanggan/ pengunjung Kantian Yuank Kota Bima. Ukuran populasi dalam penelitian ini sangat banyak dan tidak dapat diketahui dengan pasti, oleh karena itu besar sampel dihitung dengan rumus Unknown Populations: (Frendy, 2011:53).

$$
\begin{aligned}
& \mathrm{n}=\mathrm{Z}^{2} / 4 \mu^{2} \\
& \mathrm{n}=1.96^{2} / 4(0.1)^{2} \\
& \mathrm{n}=96,4
\end{aligned}
$$

Dari hasil perhitungan dengan rumus Unknown Populations, diperoleh jumlah sampel yang akan diteliti adalah sebesar 96 
orang responden/ pengunjung. Teknik pengambilan sampel menggunakan metode accidental sampling. Dimana menurut Sugiyono (2015) accidental sampling adalah mengambil responden sebagai sampel berdasarkan kebetulan, yaitu siapa saja yang secara kebetulan bertemu dengan peneliti dapat digunakan sebagai sampel bila orang yang ditemui cocok sebagai sumber data.

Teknik pengumpulan data diperoleh melalui Kuesioner, merupakan teknik pengumpulan data yang dilakukan dengan memberi seperangkat pertanyaan dan pernyataan tertulis kepada responden untuk dijawabnya, skala yang digunakan dalam penelitian ini adalah skala likert, yaitu skala yang digunakan untuk mengukur sikap, pendapat, dan persepsi seorang atau sekelompok orang tentang fenomena sosial (Sugiyono, 2017).

Teknik Analisis Data Data yang akan dianalisa dalam penelitian ini berkaitan dengan apakah adanya hubungan antara variabel bebas (independen) dengan variabel terikat (dependen). Adapun analisis data yang akan digunakan dalam penelitian ini adalah: (a) Uji Validitas dan Reliabilitas. Uji Validitas dilakukan untuk mengetahui kemampuan instrument dalam mengukur variabel penelitian. Pengujian ini dilakukan dengan mengajukan butir-butir pernyataan kuesioner yang nantinya diberikan kepada responden. Setelah mendapatkan data dari responden kemudian dilakukan uji construk validity dengan menggunakan Confirmatory Factor Analysis.

Butir-butir penyataan yang mempunyai factor loading yang valid yaitu $\geq 0,30$ menunjukkan bahwa indikatorindikator yang ada merupakan satu kesatuan alat ukur yang mengukur suatu konstruk yang sama dan dapat memprediksi apa yang seharusnya dapat diprediksi. (Ghozali, 2016). Uji validitas dalam penelitian ini menggunakan teknik analisis faktor dengan menggunakan bantuan software SPSS V.20.3. (b) Uji Reliabilitas adalah alat untuk mengukur suatu kuesioner yang merupakan indikator dari variabel. Suatu kuesioner dikatakan reliabel atau handal jika jawaban seseorang terhadap pernyataan adalah konsisten dari waktu ke waktu (Ghozali, 2016). Uji reabilitas dalam penelitian ini menggunakan bantuan software SPSS V.23.0. Uji reabilitas dalam penelitian ini menggunakan rumus Cronbach Alpha, untuk mengetahui tingkat reabilitas intrumen dari variabel sebuah penelitian.

Suatu koesioner dikatakan handal jika nilai Cronbach Alpha > o,6o (Ghozali, 2016). (c) Analisis regresi bertujuan untuk mengetahui apakah suatu persamaan regresi yang dihasilkan adalah baik untuk mengestimasi nilai variabel terikat (Sugiyono, 2013:243). (d) Koefisien Korelasi Menurut Riana (2016:270) koefisien korelasi adalah teknik untuk mengukur derajat keeratan hubungan, bukan untuk pendugaan dan peramalan. (e)Koefisien Determinasi ( $R 2)$ pada intinya mengukur seberapa jauh kemampuan model dalam menvariasi variabel dependen. Nilai koefisien determinasi adalah di antara nol dan satu. Nilai $R 2$ yang kecil berarti kemampuan variabel-variabel independen dalam menjelaskan variasi variabel dependen amat terbatas. Nilai yang mendekati satu veriabel-variabel independen memberikan hampir semua informasi yang dibutuhkan untuk memprediksi variasi dependen. (f) Uji-T digunakan untuk mengetahui seberapa jauh pengaruh satu variabel independen terhadap variabel dependen”. Derajat signifikansi yang digunakan adalah 0,05. Untuk pengambilan keputusan mengenai kebenaran ada atau tidaknya pengaruh 
variabel $\mathrm{X}$ terhadap variabel $\mathrm{Y}$, maka dilakukan pengujian hipotesis terhadap koefisien korelasi, adapun pengujian dilakukan dengan menggunakan rumus $t$ tes (uji-t).

\section{HASIL PENELITIAN PEMBAHASAN}

\section{Uji Validitas}

Uji validitas dilakukan dengan melihat korelasi antar skor masing-masing item pertanyaan dengan skor total. Besarnya $r$ tiap butir pertanyaan dapat dilihat dari tabel output SPSS pada kolom total correlation. Hasil uji validitas adalah sebagai berikut :

Tabel 1 : Hasil Uji Validitas

\begin{tabular}{|c|c|c|c|c|c|}
\hline $\begin{array}{c}\text { Variabel } \\
\text { X }\end{array}$ & $\begin{array}{c}\text { Total } \\
\text { Correl } \\
\text { ations }\end{array}$ & $\begin{array}{c}\text { Variabel } \\
\text { Y }\end{array}$ & $\begin{array}{c}\text { Total } \\
\text { Correl } \\
\text { ations }\end{array}$ & $\begin{array}{c}\text { Korelasi } \\
\text { Batas }\end{array}$ & Ket \\
\hline X. 1 & 0,581 & Y.1 & 0,488 & 0,30 & Valid \\
\hline X. 2 & 0,859 & Y. 2 & 0,763 & 0,30 & Valid \\
\hline X. 3 & 0,838 & Y. 3 & 0,809 & 0,30 & Valid \\
\hline X. 4 & 0,834 & Y.4 & 0,767 & 0,30 & Valid \\
\hline X. 5 & 0,842 & Y.5 & 0,781 & 0,30 & Valid \\
\hline X. 6 & 0,849 & Y. 6 & 0,334 & 0,30 & Valid \\
\hline X. 7 & 0,881 & Y.7 & 0,700 & 0,30 & Valid \\
\hline X. 8 & 0,871 & Y.8 & 0,704 & 0,30 & Valid \\
\hline X. 9 & 0,888 & Y.9 & 0,432 & 0,30 & Valid \\
\hline X. 10 & 0,888 & Y.10 & 0,440 & 0,30 & Valid \\
\hline
\end{tabular}

Sumber : Data diolah peneliti dengan SPSS

Hasil uji validitas ditemukan bahwa seluruh koefisien korelasi (total correlations) dari indikator variabel yang diuji nilainya lebih besar dari o,30. Hal tersebut menunjukkan bahwa total correlations lebih besar dari nilai korelasi batas. Dengan demikian seluruh indikator instrumen penelitian ini dinyatakan valid.
Uji Reliabilitas adalah alat untuk mengukur suatu kuesioner yang merupakan indikator dari variabel. Uji reabilitas dalam penelitian ini menggunakan rumus Cronbach Alpha, untuk mengetahui tingkat reabilitas intrumen dari variabel sebuah penelitian. Suatu koesioner dikatakan handal jika nilai Cronbach Alpha > o,60. Hasil uji reliabilitas adalah sebagai berikut :

Tabel 2 : Hasil Uji Reliabilitas

\begin{tabular}{|c|c|c|c|}
\hline $\begin{array}{c}\text { Variabel } \\
\text { Penelitian }\end{array}$ & $\begin{array}{c}\text { Cronbac } \\
\text { h Alpha }\end{array}$ & $\begin{array}{c}\text { Cut of } \\
\text { Value }\end{array}$ & $\begin{array}{c}\text { Keterang } \\
\text { an }\end{array}$ \\
\hline $\begin{array}{c}\text { Kualitas } \\
\text { Pelayanan } \\
\text { (X) }\end{array}$ & 0,952 & 0,600 & Reliable \\
\hline $\begin{array}{c}\text { Minat Beli } \\
\text { (Y) }\end{array}$ & 0,816 & 0,600 & Reliable \\
\hline
\end{tabular}

Sumber : Data diolah peneliti dengan SPSS

Uji reliabilitas yang dilakukan terhadap setiap instrumen penelitian pada tabel 2 di atas diperoleh nilai Cronbach's Alpha pada tiap instrumen penelitian variabel Kualitas Pelayanan yaitu sebesar o,952 dan Cronbach Alpha untuk variabel Minat Beli adalah sebesar o,816 ini menunjukkan nilai yang lebih besar dari o,60. Hal tersebut menunjukkan bahwa semua instrumen peneltian ini adalah reliable.

\section{Pengujian Hipotesis}

Pengujian hipotesis dalam penelitian bertujuan untuk mengetahui ada tidaknya pengaruh variabel $\mathrm{X}$ terhadap variabel $\mathrm{Y}$.

\section{Analisis Regresi Linier}

Hasil analisis regresi linier sederhana dengan menggunakan program SPSS 23.0 adalah sebagai berikut :

\section{Uji Reliabilitas}


Tabel 3 : Regresi Linier Sederhana Coefficients $^{a}$

\begin{tabular}{|c|c|c|c|c|c|}
\hline \multirow[b]{2}{*}{ Model } & \multicolumn{2}{|c|}{$\begin{array}{c}\text { Unstandardized } \\
\text { Coefficients }\end{array}$} & \multirow{2}{*}{$\begin{array}{c}\begin{array}{c}\text { Standardized } \\
\text { Coefficients }\end{array} \\
\text { Beta }\end{array}$} & \multirow[b]{2}{*}{$\mathrm{T}$} & \multirow[b]{2}{*}{ Sig. } \\
\hline & B & $\begin{array}{l}\text { Std. } \\
\text { Error }\end{array}$ & & & \\
\hline $1 \quad$ (Constant) & 26.988 & 2.719 & & 9.926 & .000 \\
\hline $\begin{array}{l}\text { Kualitas } \\
\text { Pelayanan }\end{array}$ & .369 & .064 & .509 & $5 \cdot 729$ & .000 \\
\hline
\end{tabular}

a. Dependent Variable: Minat Beli

Sumber : Data diolah peneliti dengan SPSS

Berdasarkan hasil analisis regresi linier sederhana pada tabel 3 di atas diketahui bahwa nilai kostanta (a) sebesar 26,988 dan nilai koefisien regresi (b) sebesar 0,369, dan dimasukkan dalam persamaan regresi sederhana sebagai berikut:

$$
\mathrm{Y}=26,988+0,369 \mathrm{X} \text {. }
$$

$\mathrm{Y}=\mathrm{a}+\mathrm{bX}$ dapat dijelaskan sebagai berikut:

Nilai konstanta variabel kualitas pelayanan bernilai positif yaitu sebesar 26,988, nilai konstanta tersebut menunjukkan bahwa jika tidak terjadi peningkatan nilai variabel kualitas pelayanan atau bernilai o (nol) maka minat beli pelanggan di masa pandemik covid 19 pada Kantin Yuank tetap bernilai sebesar 26,988 satuan. Nilai koefisien regresi minat beli bernilai positif yaitu sebesar 0,369 artinya setiap terjadi kenaikan nilai kualitas pelayanan 1\%, maka akan dapat meningkatkan minat beli pelanggan di masa pandemik covid 19 pada Kantin Yuank sebesar 0,369 satuan.

\section{Koefisien Korelasi Product Moment}

Uji korelasi product moment bertujuan untuk mencari keeratan hubungan (asosiasi) antara variabel Kualitas Pelayanan terhadap Minat Beli. Hasil uji koefisien korelasi product moment dapat disajikan pada tabel 4.4 sebagai berikut:
Tabel 4 : Koefisien Korelasi Model Summary

\begin{tabular}{|l|c|r|r|c|}
\hline Model & \multicolumn{1}{|c|}{$\mathrm{R}$} & $\begin{array}{c}\mathrm{R} \\
\text { Square }\end{array}$ & $\begin{array}{c}\text { Adjusted } \\
\text { R Square }\end{array}$ & $\begin{array}{c}\text { Std. Error } \\
\text { of the } \\
\text { Estimate }\end{array}$ \\
\hline 1 & $.509^{\mathrm{a}}$ & .259 & .251 & 4.00953 \\
\hline
\end{tabular}

a. Predictors: (Constant), Kualitas Pelayanan Sumber : Data diolah peneliti dengan SPSS

Nilai koefisien korelasi (R) pada tabel 4 di atas yaitu sebesar 0,509 atau sebesar $50,9 \%$ dan berada pada interval koefisien koerlasi (0,40-0,599) dengan tingkat hubungan yang sedang. Dengan demikian dapat diketahui bahwa kualitas pelayanan memiliki keeratan hubungan yang cukup kuat terhadap minat beli pengunjung pada masa pandemik covid 19 di Kantin Yuank.

\section{Analisis Determinasi}

Koefisien Determinasi (Adjusted $\mathrm{R}$ Square) bertujuan untuk mengetahui seberapa besar kemampuan/kontribusi variabel independen menjelaskan variabel dependen. Besarnya kontribusi variabel kualitas pelayanan terhadap Minat Beli di masa pandemik covid 19 pada Kantin Yuank Kota Bima dapat ditunjukan berdasarkan nilai Adjusted $R$ Square pada tabel 4 di atas yaitu sebesar 0,251. Nilai Adjusted $R$ Square tersebut menunjukan bahwa kontribusi variabel Kualitas Pelayanan terhadap Minat Beli pengunjung pada masa pandemik covid 19 di Kantin Yuank Kota Bima adalah sebesar $25,1 \%$ dan sisanya $74,9 \%$ disebabkan oleh faktor lain yang tidak termasuk dalam penelitian ini seperti kualitas produk, harga, tempat dan lainlain.

\section{Uji - t}

Uji-t digunakan untuk mengetahui ada tidaknya pengaruh yang signifikan antara Kualitas Pelayanan terhadap Minat Beli. 
Tabel 5 : Uji-T

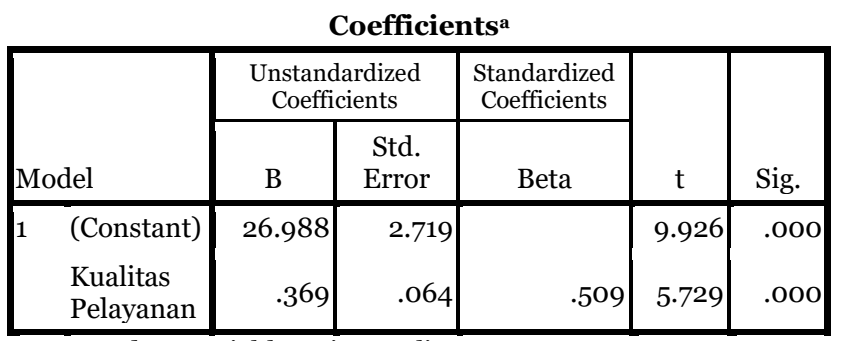

a. Dependent Variable: Minat Beli

Sumber : Data diolah peneliti dengan SPSS

Hasi Uji-T terhadap pengaruh kualitas pelayanan terhadap minat beli pada masa pandemik covid 19 di Kantin Yuank Kota Bima menunjukkan niai uji signifikansi (ujit) yang menghasilkan nilai t-hitung bernilai positif yaitu sebesar 5,729 lebih besar dari ttabel $=1,986$ dengan nilai sig (signifikansi) lebih kecil dari 0,05 $(0,000<0,05)$. Dengan demikian dapat dikatakan bahwa hipotesis Ha diterima yaitu kualitas pelayanan berpengaruh positif dan signifikan terhadap minat beli di masa pandemik covid 19 pada Kantin Yuank Kota Bima. hal ini menunjukkan bahwa kualitas pelayanan dapat mempengaruhi minat beli konsumen/pengunjung jika Kantin Yuank memberikan pelayanan yang baik terhadap pengunjung atau pelanggan, sehingga kualitas pelayanan tersebut membuat minat pengunjung dapat meningkat.

Pada masa pandemi saat ini, social dan physical distancing membatasi waktu dan kesempatan orang untuk berkumpul dan keluar rumah, namun dalam menumbuhkan minat beli pelanggan Kantin Yuank berupaya meningkatkan minat beli pelanggan dengan cara penataan jarak tempat duduk dan menyediakan tempat cuci tangan serta pemakain masker dan penyemprotan hand sanitizer kepada pengunjung. Selain itu Kantian Yuank Kota Bima memberikan kualitas pelayanan yang baik kepada para pengunjung, dimana ketika kualitas pelayanan baik maka pelanggan akan merasa senang dan akan kembali lagi untuk membeli dan tidak akan menjatuhkan pilihanya kepada pesaing. Dalam artian ketika kualitas layanan baik maka minat membeli konsumen akan bertambah. Sebaliknya kualitas pelayanan kurang baik maka akan menurunkan minat membeli pelanggan.

Hasil ini sejalan dengan penelitian sebelumnya yang dilakukan oleh Marieta (2017) Hasil penelitian ini menunjukkan bahwa kualitas pelayanan memiliki pengaruh terhadap minat beli konsumen pada Leggen Coffy Jogjakarta. Selanjutnya penelitian dari Ananda (2016) Hasil penelitian ini mengatakan bahwa kualitas pelayanan memiliki pengaruh terhadap minat beli konsumen pada Ramayana Lestari Sentosa Pekanbaru.

\section{Kesimpulan}

Berdasarkan hasil analisis dan pembahasan yang telah dikemukakan pada bagian sebelumnya, maka dapat disimpulkan bahwa kualitas pelayanan berpengaruh positif dan signifikan terhadap minat beli pengunjung di masa pandemik covid 19 pada Kantin Yuank Kota Bima. hal ini menunjukkan bahwa jika kualitas pelayanan yang baik seperti keterampilan karyawan dalam memberikan pelayanan, kecepatan, dan kesigapan dalam melayani pelanggan serta penerapan protokol kesehatan di masa pandemik covid 19 ditingkatkan dengan cara membersihkan ruangan, penyediaan alat cuci tangan, pemakaian sarung tangan bagi karyawan, pemakain masker dan penyemprotan hand sanitizer serta penataan jarak tempat duduk dapat mempengaruhi minat beli pengunjung pada Kantin Yuank Kota Bima.

\section{Saran}


Berdasarkan kesimpulan tersebut maka dapat diajukan saran kepada karyawan Kantin Yuank Kota Bima dan peneliti selanjutnya yaitu:

1. Kualitas pelayanan pada Kantin Yuank diharapkan dapat dipertahankan dan ditingkatkan khususnya pada kualitas pelayanan seperti keterampilan karyawan dalam memberikan pelayanan, kecepatan, dan kesigapan dalam melayani pengunjung / pelanggan.

2. Kantin Yuank perlu memberikan nilai bagi pelanggan dengan cara memberikan manfaat yang sanggup memenuhi kebutuhan dan harapan pelanggan seperti meningkatkan kualitas produk makanan dan minuman yang disediakan

3. Penelitian selanjutnya sebaiknya dapat dilengkapi dengan variabel lain yang mempengaruhi minat beli seperti variabel produk, harga, dan emosi. Harapannya adalah agar terciptanya generalisasi teori tentang faktor-faktor yang mempengaruhi minat beli pelanggan khususnya pada Kantian Yuank Kota Bima.

\section{DAFTAR PUSTAKA}

Adhiyanto, Mochlas. (2012). Analisis Pengaruh Kualitas Pelayanan Terhadap Kepuasan Pelanggan Menggunakan Jasa Balai Latihan Kerja Industri (Blki) Semarang. Skripsi Program Studi S1 Fakultas Ekonomi Universitas Diponegoro. 169.

Ananda. (2016). Pengaruh Kualitas Pelayanan terhadap Minat Beli konsumen pada Ramayana Lestari Sentosa Pekanbaru. Jom FISIP. Vol. 3 No. 1

Arikonto, S. (2016). Prosedur Penelitian Suatu Pendekatan Praktik. Rineka Cipta

Bariroh. (2015). Jurnal Psikologi. Pengaruh Kualitas Pelayanan terhadap Minat
Beli Konsumen pada Minimarket Indomaret dan Minimarket Alfamart. Univerisitas Islam Negeri Maulana Malik Ibrahim Malik.Malang.

Dwityanti, Esthi (2008). Analisis FaktorFaktor Yang Mempengaruhi Minat Beli Konsumen Terhadap Layanan Internet Banking Mandiri Studi Kasus Pada Karyawan Departemen Pekerjaan Umum Jakarta. Masters Thesis, Program Pascasarjana Universitas Diponegoro

Frendy. (2011). Metode Penelitian Untuk Bisnis, Jakarta. Salemba Empat

Ghozali, Imam. (2016). Aplikasi Analisis Multivariete Dengan Program IBM SPSS 23 (Edisi 8). Cetakan ke VIII. Semarang : Badan Penerbit Universitas Diponegoro

Kertajaya, Hermawan. (2015). Marketing In Challenging Times. Jakarta: Penerbit. PT Gramedia Pustaka Utama

Kinnear, T.C. dan Taylor, J.R. (2010). Marketing Research: An Applied Approach, 5th ed. New York: McGraw Hill

Lovelock, Christopher, Jochen Wirtz, \& Jacky Mussry. (2011). Pemasaran Jasa. Edisi 7. Jakarta. Erlangga

Murdayani, M., Nurbaiti, B., \& Soehardi, S. (2021). The Effect of the Marketing Mix of MSME Products on Sales Volume During the Covid-19 Pandemic The Effect of the Marketing Mix of MSME Products on Sales Volume During the Covid-19 Pandemic. Journal of Strategic and Global Studies, 4(2), 27-40. https://doi.org/https://doi.org/http s://doi.org/10.7454/jsgs.v4i2.1043

Nazir, M. (2014). Metode Penelitian. Ghalia Indonesia

Prilando Dwi, Marieta. (2017). Pengaruh Kualitas Pelayanan terhadap Minat Beli Konsumen pada Leggen Coffy. 
Jurnal Manajemen Universitas

Sanata Dharma Yogyakarta.

Parasuraman, A., Zeithaml, V.A., and Berry, L.L., (2011), A Copceptual Model of Service Quality and Its Implications for Future Research", Journal of Marketing, Vol 49, Fall, pp. 41-50

Soehardi, S. (2021). Model Peningkatan Volume Penjualan Melalui Kualitas Produk, Kualitas Pelayanan Dan Loyalitas Kopi Golda. Jurnal Manajemen Strategi Dan Aplikasi Bisnis, 4(2), 353-360. https://doi.org/http://ejournal.imp eriuminstitute.org/index.php/JMSA $\mathrm{B} /$ article/view/398

Sugiyono. (2015). Metode Penelitian Kuantitatif. Kualitatif dan $R \& D$. Bandung Alfabeta

Sunyoto, Danang. (2012). Konsep Dasar Riset Pemasaran dan Perilaku Konsumen, Cetakan Pertama. Yogyakarta. CAPS (Center for Academic Publishing Service).

Thamrin \& Tantri Francis. (2012). Manajemen Pemasaran. Jakarta : Raja Grafindo Persada.

Tjiptono, Fandy dan Chandra, Gregorius. (2011). Service, Quality, and Satisfaction. Edisi Pertama. Yogyakarta : Andi Offset.

Tifa. (2010). Pengaruh Kualitas Pelayanan terhadap Minat Beli konsumen pada Rumah Makan Boga Bogi Jogjakarta. Jurnal Information Management. Edisi September Vo. 1 No. 21 